\title{
PERAN PERANGKAT DESA DALAM PENGELOLAAN DANA DESA DI DESA RANTAUPANJANG KIRI KECAMATAN KUBU KABUPATEN ROKANHILIR PROVINSI RIAU
}

Oleh

\author{
Helwani \\ Institut Pemerintahan Dalam Negeri \\ helwanisamuel10@gmail.com
}

\begin{abstract}
$L$ aw of the Republic of Indonesia Number 6 of 2014 concerning Villages governing Village Boundaries,
\end{abstract}

Village Governments, Village Consultative Bodies (BPD), village gratuities, and others. Whereas in Law Number 22 of 1999 which has been revised through Law Number 32 of 2004 concerning Village Governance. Furthermore, the law regulates the existence of government organizations in the village.

Village officials have an important role in village development, because the allocation of village funds is certainly governed by village officials, income to expenditure as well as the transfer of funds from the APBN that enters the village and becomes the Village APB is certainly the responsibility of village officials. This research method uses descriptive qualitative method with data collection techniques through interviews and data. As a result of this study, village officials in Desa Rantaupanjang Kiri allocate village funds accordingly. Apply all components of the village budget such as income, village expenditure and financing. Also performs the stages of managing funds from planning to accountability. There were several hambatan felt in the allocation of village funds, namely weather, late disbursement of village money and also village access that was difficult to reach. Keywords: village governance, budget, income

\begin{abstract}
Abstrak
$\mathrm{U}$ ndang-Undang Nomor 6 Tahun 2014 tentang Desa yang mengatur tentang Batas Wilayah Desa, Pemerintahan Desa, Badan Permusyawaratan Desa (BPD), peraturan Desa, dan lain-lain. Sedangkan dalam Undang Nomor 22 Tahun 1999 yang telah direvisi melalui UndangUndang Nomor 32 Tahun 2004 tentang Pemerintahan Desa. Lebih lanjut undangundang tersebut mengatur tentang keberadaan organisasi pemerintahan yang berada di desa. Perangkat desa memiliki peran penting dalam pembangunan desa, karena pengalokasian dana desa tentunya diatur oleh perangkat desa, pemasukan hingga pengeluaran juga transfer dana dari APBN yang masuk ke desa dan menjadi APBDesa tentunya menjadi tanggung jawab para perangkat desa. Metode penelitian ini menggunakan metode kualitatif deskriptif dengan teknik pengumpulan data melalui wawancara dan data. Hasil dari penelitian ini, para perangkat desa di Desa Rantaupanjang Kiri melakukan pengalokasian dana desa sesuai dengan semestinya. Menerapkan seluruh komponen anggaran desa seperti pendapatan, belanja desa dan pembiayaan. Juga melakukan tahapan pengelolaan dana dari perencanaan hingga pertanggungjawaban. Terjadi beberapa hambatan yang dirasakan dalam pengalokasian dana desa, yakni cuaca, terlambatnya pencairan uang desa dan juga akses desa yang sulit ditempuh.
\end{abstract}

Kata kunci: pemerintahan desa, anggaran desa, pendapatan desa 


\section{PENDAHULUAN}

esa merupakan salah satu pembagian

$\mathrm{D}$ wilayah administratif di bawah kecamatan yang juga diatur oleh pemerintah yang dipimpin oleh kepala desa. Desa memiliki peran yang penting, khususnya dalam pelaksanaan tugas di bidang pelayanan publik.Desa sendiri terdiri dari beberapa wilayah-wilayah kecil yang biasa disebut kampung. Desa sendiri telah diatur perundangundangan dalam UndangUndang Nomor 6 Tahun 2014 tentang Desa yang mengatur tentang Batas Wilayah Desa, Pemerintahan Desa, Badan Permusyawaratan Desa (BPD), peraturan Desa, dan lain-lain. Sedangkan dalam Undang Nomor 22 Tahun 1999 yang telah direvisi melalui Undang-Undang Nomor 32 Tahun 2004 tentang Pemerintahan Desa. Lebih lanjut Undang-undang tersebut mengatur tentang keberadaan organisasi pemerintahan yang berada di desa. Ke depannya diharapkan setiap desa, supaya bisa melakukan proses pembangunan di daerahnya masing-masing dengan mengatur dan mengurus sendiri rumah tangganya. Dalam pembangunan desa tentunya dibutuhkan dana dalam prosesnya, dana tersebut berasal dari APBN, jumlah alokasi anggaran yang langsung ke desa, ditetapkan sebesar $10 \%$ dari dan di luar dana transfer daerah. Kemudian dipertimbangkan jumlah penduduk, angka kemiskinan, luas wilayah, kesulitan geografi.

Menurut hasil evaluasi Kementerian Keuangan pada 2015-2016 hasil output dari dana desa di berbagai daerah menghasilkan pembangunan yang bermanfaat bagi masyarakat Desa, yakni $95.200 \mathrm{~km}$ jalan desa, $914.000 \mathrm{~km}$ jembatan desa, 22.616 unit penyalur air bersih, 4.004 unit polides, dan masih banyak lagi. Dari hasil tersebut tentunya banyak pihak yang berpartisipasi dalam pembangunan desa, baik masyarakat, Badan Permusyawaratan Desa, PKK, dan tentunya para perangkat desa. Perangkat desa memiliki peran penting dalam pembangunan desa, karena pengalokasian dana desa tentunya diatur oleh perangkat desa, pemasukan hingga pengeluaran juga transfer dana dari APBN yang masuk ke desa dan menjadi APBDesa tentunya menjadi tanggung jawab para perangkat desa.

Peran perangkat desa tentunya sangat penting bagi pengalokasian dana desa, di mana tiap tahunnya anggaran yang diberikan kepada desa untuk pengembangan daerah semakin tinggi, maka diharapkan hasil kerja yang efektif, efisien dan akuntabel dari aparatur desa. Penelitian ini bertujuan untuk mengetahui peran perangkat desa dalam pengalokasian dana desa di Desa Rantaupanjang Kiri, Kecamatan Kubu yang meliputi, pelaksanaan, pelaporan dan petanggungjawaban atas dana yang diterima.

\section{Rumusan Masalah}

1. Bagaimana peran perangkat desa di desa Rantaupanjang Kiri, Kecamatan Kubu dalam pengelolaan anggaran dana desa?

2. Apa hambatan dalam pengelolaan anggaran dan desa di Desa

Rantaupanjang Kiri, Kecamatan Kubu?

\section{Tujuan Penelitian}

1. Untuk mengetahui peran perangkat desa di desa Rantaupanjang kiri, Kecamatan Kubu Kabupaten Rokanhilir dalam pengelolaan anggaran dana desa

2. Untuk mengetahui hambatan dalam pengelolaan anggaran dan desa di Desa Rantaupanjang kiri Kecamatan Kubu

Kabupaten Rokanhilir

\section{KAJIAN PUSTAKA}

\section{Pengelolaan}

Dalam Kamus Besar Bahasa Indonesia (KBBI) disebutkan bahwa pengelolaan adalah proses atau cara perbuatan mengelola atau proses melakukan kegiatan tertentu dengan menggerakkan tenaga orang lain, proses 
yang membantu merumuskan kebijaksanaan dan tujuan organisasi atau proses yang memberikan pengawasan pada semua hal yang terlibat dalam pelaksanaan kebijaksanaan dan pencapaian tujuan.

$\begin{array}{rccc}\text { Marry } & \text { Parker } & \text { Follet (1997) } & \text { dalam } \\ \text { Tisnawati } & \text { dan } & \text { Saefullah } & \text { (2009) }\end{array}$
mendefinisikan pengelolaan adalah seni atau proses dalam menyelesaikan sesuatu yang terkait dengan pencapaian tujuan. Dalam penyelesaian akan sesuatu tersebut, terdapat tiga faktor yang terlibat:

- Adanya penggunaan sumber daya organisasi, baik sumber daya manusia maupun faktor-faktor produksi lainnya.

- Proses yang bertahap mulai dari perencanaan, pengorganisasian, pengarahan dan pengimplementasian, hingga pengendalian dan pengawasan.

- Adanya seni dalam penyelesaian pekerjaan.

\section{Desa}

Desa menurut H.A.W. Widjaja dalam bukunya yang berjudul Otonomi Desa (2005) menyatakan bahwa: Desa adalah sebagai kesatuan masyarakat hukum yang mempunyai susunan asli berdasarkan hak asal-usul yang bersifat istimewa. Landasan pemikiran dalam mengenai Pemerintahan Desa adalah keanekaragaman, partisipasi, otonomi asli, demokratisasi dan pemberdayaan masyarakat.

Dalam ketentuan umum UU Nomor 32 Tahun 2004 tentang pemerintah daerah menyatakan, desa atau yang disebut nama lain, selanjutnya disebut desa adalah kesatuan masyarakat hukum yang memiliki batas wilayah yang berwenang untuk mengatur dan mengurus kepentingan masyarakat setempat, berdasarkan asal usul dan adat istiadat setempat yang diakui dan dihormati dalam sistem pemerintahan negara kesatuan Republik Indonesia. Dalam UU tersebut juga ditegaskan desa adalah kesatuan masyarakat hukum yang memiliki batas wilayah yang berwenang untuk mengatur dan mengurus urusan pemerintahan, kepentingan masyarakat setempat berdasarkan prakarsa masyarakat, hak-asal usul dan atau hak tradisional yang diakui dan dihormati dalam sistem pemerintahan negara kesatuan Republik Indonesia.

Tujuan pembentukan desa adalah untuk meningkatkan kemampuan penyelenggaraan Pemerintahan secara berdaya guna dan berhasil guna dan peningkatan pelayanan terhadap masyarakat sesuai dengan tingkat perkembangan dan kemajuan pembangunan. Dalam menciptakan pembangunan hingga di tingkat akar rumput, maka terdapat beberapa syarat yang harus dipenuhi untuk 14 pembentukan desa, yakni: pertama, faktor penduduk, minimal 2.500 jiwa atau 500 kepala keluarga, kedua, faktor luas yang terjangkau dalam pelayanan dan pembinaan masyarakat, ketiga, faktor letak yang memiliki jaringan perhubungan atau komunikasi antar dusun, keempat, faktor sarana prasarana, tersedianya sarana perhubungan, pemasaran, sosial, produksi, dan sarana pemerintahan desa, kelima, faktor sosial budaya, adanya kerukunan hidup beragama dan kehidupan bermasyarakat dalam hubungan adat istiadat, keenam, faktor kehidupan masyarakat, yaitu tempat untuk keperluan mata pencaharian masyarakat.

\section{Struktur Pemerintahan Desa}

Sesuai dengan Undang-Undang Nomor 6 Tahun 2014 tentang Desa Pasal 25 bahwa Pemerintah Desa adalah Kepala Desa atau yang disebut dengan nama lain dan yang dibantu oleh perangkat desa atau yang disebut dengan nama lain. Dalam ilmu manajemen pembantu pimpinan disebut staf. Staf profesional diartikan sebagai pegawai, yaitu pimpinan yang memiliki keahlian dalam bidangnya, bertanggung jawab, dan berperilaku profesional dalam menjalankan tugasnya. 


\section{Peran Perangkat Desa}

Dalam Permendagri Nomor 84 Tahun 2015 tentang Susunan Organisasi dan Tata Kerja Pemerintah Desa (SOTK) mulai dari Pasal 6 sampai Pasal 10 disebutkan bahwa, kepala desa dan perangkat desa mempunyai tugas dan fungsi di antaranya sebagai berikut.

1. Pasal 6 menjelaskan tentang Tugas dan Fungsi Kepala Desa berbunyi :

- Kepala Desa berkedudukan sebagai Kepala Pemerintah Desa yang memimpin penyelenggaraan Pemerintahan Desa.

- Kepala Desa bertugas menyelenggarakan Pemerintahan Desa, melaksanakan pembangunan, pembinaan kemasyarakatan, dan pemberdayaan masyarakat.

2. Pasal 7 menjelaskan tentang Tugas dan Fungsi Sekretaris Desa yang berbunyi :

- Sekretaris Desa berkedudukan sebagai unsur pimpinan Sekretariat Desa.

- Sekretaris Desa bertugas membantu Kepala Desa dalam bidang administrasi pemerintahan.

3. Pasal 8 menjelaskan tentang Tugas dan Fungsi Kepala Urusan (Kaur) bidang Tata Usaha dan Umum, Keuangan dan Perencanaan berbunyi:

- Kepala urusan berkedudukan sebagai unsur staf sekretariat.

- Kepala urusan bertugas membantu Sekretaris Desa dalam urusan pelayanan administrasi pendukung pelaksanaan pemerintahan.

4. Pasal 9 menjelaskan tentang Tugas dan Fungsi Kepala Seksi Pemerintahan, Kesejahteraan Rakyat dan Pelayanan berbunyi:
- Kepala seksi berkedudukan sebagai unsur pelaksana teknis.

- Kepala seksi bertugas membantu Kepala Desa sebagai pelaksana tugas operasional.

5. Pasal 10 menjelaskan tentang Tugas dan Fungsi Kepala Urusan Kewilayahan/ Kepala Dusun (Kadus) berbunyi:

Kepala Kewilayahan atau sebutan lainnya berkedudukan sebagai unsur satuan tugas kewilayahan yang bertugas membantu Kepala Desa dalam pelaksanaan tugasnya di wilayahnya.

\section{Pengelolaan Dana Desa}

Peraturan Menteri Dalam Negeri Nomor 37 tahun 2007 tentang Pedoman Pengelolaan Keuangan Desa. Pemerintah daerah mempunyai kewenangan yang lebih luas dalam pengelolaan daerahnya. Salah satu bentuk kepedulian pemerintah terhadap pengembangan wilayah perdesaan adalah adanya anggaran pembangunan secara khusus yang dicantumkan dalam Anggaran Pendapatan dan Belanja Daerah (APBD) untuk pembangunan wilayah perdesaan, yakni dalam bentuk Alokasi Dana Desa (ADD). Inilah yang kemudian melahirkan suatu proses baru tentang desentralisasi desa diawali dengan digulirkannya Alokasi Dana Desa (ADD).

Pemerintah desa wajib mengelola keuangan desa secara transparan, akuntabel, partisipatif serta dilakukan dengan tertib dan disiplin. Transparan artinya dikelola secara terbuka, akuntabel artinya dipertanggungjawabkan secara legal, dan partisipatif artinya melibatkan masyarakat dalam penyusunannya. Keuangan desa harus dibukukan dalam sistem pembukuan yang benar sesuai dengan kaidah sistem akuntansi keuangan pemerintahan (Nurcholis,2011: 82).

Menurut Nyoman (2005: 24) Desa sebagai kepala pemerintahan desa adalah pemegang kekuasaan pengelola keuangan 
desa dan mewakili pemerintahan desa dalam kepemilikan kekayaan desa yang dipisahkan. Oleh karena itu, Kepala Desa mempunyai kewewenanga:

a. Menetapkan kebijakan tentang pelaksanaan APBDesa.

b. Menetapkan kebijakan tentang pengelolaan barang desa.

c. Menetapkan bendahara desa.

d. Menetapkan petugas yang melakukan pemungutan penerimaan desa dan.

e. Menetapkan petugas yang melakukan pengelolaan barang milik desa.

Dalam Peraturan Pemerintah Nomor 43 Tahun 2014 tentang Desa Pasal 93 pengelolaan keuangan desa meliputi: a. Perencanaan;

b. Pelaksanaan;

c. Penatausahaan;

d. Pelaporan; dan

e. Pertanggungjawaban;

Kepala Desa adalah pemegang kekuasaan pengelolaan keuangan desa, dalam melaksanakan kekuasaan pengelolaan keuangan desa kepala desa menguasakan sebagian kekuasaannya kepada perangkat desa. Berdasarkan Peraturan Pemerintah Nomor 43 Tahun 2014 tentang desa pengelolaan keuangan desa dilaksanakan dalam masa satu tahun anggaran terhitung mulai tanggal 1 Januari sampai dengan 31 Desember.

\section{Komponen dalam Anggaran Desa}

Menurut Permendagri Nomor 113 Tahun 2014 komponen anggaran tersebut terdiri atas akun-akun sebagai berikut.

\section{Pendapatan}

Menurut Permendagri Nomor 113 Tahun 2014 Pendapatan Desa meliputi semua penerimaan uang melalui rekening desa yang merupakan hak desa dalam satu tahun anggaran yang tidak perlu dibayar kembali oleh desa. Pendapatan desa dapat berasal dari:

\section{a. Pendapatan Asli Desa}

- Hasil usaha desa. Contoh desa mempunyai badan usaha milik desa (Bumdes) bidang usaha pembuatan batik, hasilnya masuk dalam hasil usaha desa.

- Hasil kekayaan desa. Contoh tanah kas desa, pasar desa, bangunan desa, wisata yang dikelola desa, pemandian desa, hutan desa, dll.

- Hasil swadaya dan partisipasi masyarakat adalah membangun dengan kekuatan sendiri yang melibatkan peran serta masyarakat berupa tenaga atau barang yang dinilai dengan uang, contoh: urunan desa, urunan carik, iuran penitipan kendaraan.

- Lain-lain pendapatan asli desa. Contoh ganti ongkos cetak suratsurat, biaya legalisasi suratsurat, sewa tanah desa

b. Transfer

- Dana Desa adalah sumber dana yang berasal dari anggaran pendapatan dan belanja negara ditransfer melalui anggaran pendapatan dan belanja daerah Kabupaten/Kota dan digunakan untuk menyelenggarakan pemerintahan, pembangunan desa, pembinaan, dan pemberdayaan masyarakat.

- Bagi hasil pajak daerah Kabupaten/ Kota dan retribusi daerah. Misalnya: bagi hasil pajak bumi dan bangunan.

- Alokasi Dana Desa (ADD) adalah dana yang dialokasikan oleh kabupaten untuk desa. Sumber ADD ini adalah dana perimbangan pusat 
dan daerah yang diterima kabupaten untuk desa.

- Bantuan keuangan APBD Pemprov, Kab./Kota

c. Kelompok pendapatan lain-lain, jenis:

- Hibah dan sumbangan pihak ketiga yang tidak mengikat dapat berbentuk hadiah, donasi, wakaf, hibah atau sumbangan lain. Sumbangan yang berbentuk barang (bergerak maupun tidak bergerak) dicatat sebagai barang inventaris kekayaan milik desa sesuai UU, dapat juga berbentuk uang, tetapi tidak mengikat.

- Lain-lain pendapatan desa yang sah, antara lain hasil kerja sama dengan pihak ketiga, bantuan perusahaan yang berlokasi di desa.

\section{Belanja Desa}

Menurut Permendagri Nomor 113 Tahun 2014 belanja desa meliputi semua pengeluaran dari rekening desa yang merupakan kewajiban desa dalam satu tahun anggaran yang tidak akan diperoleh pembayarannya kembali oleh desa. Belanja desa dipergunakan dalam rangka mendanai penyelenggaraan kewenangan desa. Belanja desa terdiri dari:

\section{a. Belanja Bidang Penyelenggaraan}

Pemerintah Desa

Belanja ini meliputi beberapa jenis, yaitu:

- Penghasilan tetap dan tunjangan, ini terdiri dari belanja pegawai (penghasilan tetap kepala desa, tunjangan kepala desa, tunjangan BPD).

- Operasional perkantoran terdiri dari:

(i) Belanja barang dan jasa, misalnya belanja alat tulis kantor, benda pos, bahan/material, pemeliharaan, cetak/penggandaan, sewa kantor desa, sewa perlengkapan dan peralatan kantor, makanan dan minuman rapat, pakaian dinas dana atributnya, perjalanan dinas, upah kerja, honorarium narasumber/ ahli, operasional Pemerintah Desa, operasional BPD, insentif Rukun Tetangga/Rukun Warga (bantuan untuk operasional lembaga RT/ RW dalam rangka membantu pelaksanaan tugas pelayanan pemerintahan, perencanaan pembangunan, ketenteraman dan ketertiban, serta pemberdayaan masyarakat desa), dan pemberian barang pada masyarakat/kelompok masyarakat dilakukan untuk menunjang pelaksanaan kegiatan.

(ii) Belanja modal digunakan untuk pengeluaran dalam rangka pembelian/pengadaan barang atau bangunan yang nilai manfaatnya lebih dari dua belas bulan. Pembelian/pengadaan barang atau bangunan digunakan untuk kegiatan penyelenggaraan kewenangan desa, misalnya: beli komputer, beli meja.

b. Bidang Pelaksanaan Pembangunan Desa

Belanja jenis ini merupakan belanja yang digunakan untuk pembangunan desa, contoh perbaikan saluran irigasi, pengaspalan jalan, dll.

c. Bidang Pembinaan Kemasyarakatan

Belanja jenis ini digunakan untuk pembinaan masyarakat desa, misalnya pendanaan untuk pelatihan perangkat desa, pendanaan untuk kegiatan taruna.

d. Bidang Pemberdayaan Masyarakat

Belanja jenis ini digunakan untuk pemberdayaan masyarakat desa, misalnya pendanaan untuk pengelolaan lingkungan hidup, pengelolaan sampah mandiri.

e. Bidang tak Terduga 
Belanja ini digunakan untuk hal-hal yang tidak terduga. Kegiatan dalam keadaan darurat dianggarkan dalam belanja tidak terduga, misalnya kegiatan sosial bencana.

\section{Pembiayaan}

Menurut Permendagri Nomor 113 Tahun 2014 Pembiayaan Desa meliputi semua penerimaan yang perlu dibayar kembali dan/atau pengeluaran yang akan diterima kembali, baik pada anggaran yang bersangkutan maupun pada tahun anggaran berikutnya. Pembiayaan terdiri dari:

a. Penerimaan pembiayaan mencakup:

- Sisa lebih perhitungan anggaran (Silpa) tahun sebelumnya

$\begin{array}{lr}\text { Mencakup } & \text { pelampauan } \\ \text { penerimaan } & \text { pendapatan } \\ \text { terhadap } & \text { belanja, } \\ \text { penghematan belanja, sisa } & \text { banan } \\ \text { dana kegiatan lanjutan. Hal } \\ \text { tersebut seperti kelebihan } \\ \text { penerimaan pendapatan asli } \\ \text { desa, kelebihan penerimaan } \\ \text { alokasi dana desa, kelebihan } \\ \text { penerimaan lain-lain, } \\ \text { kelebihan penerimaan } \\ \text { pembiayaan, penghematan } \\ \text { belanja, sisa dana kegiatan. } \\ \text { Silpa juga merupakan sisa } \\ \text { lebih tahun anggaran } \\ \text { sebelumnya. }\end{array}$

Silpa menutupi defisit anggaran apabila realisasi pendapatan lebih kecil daripada realisasi belanja, mendanai pelaksanaan kegiatan lanjutan, dan mendanai kewajiban lainnya yang sampai dengan akhir tahun anggaran belum diselesaikan.
- Pencairan dana cadangan digunakan untuk menganggarkan pencairan dana cadangan dari rekening dana cadangan ke rekening kas desa dalam tahun anggaran berkenaan. Dana cadangan tidak dapat digunakan untuk membiayai kegiatan di luar yang sudah ditetapkan sebelumnya dalam peraturan desa tentang pembentukan dana cadangan.

- Hasil penjualan kekayaan desa yang dipisahkan digunakan untuk menganggarkan hasil penjualan kekayaan desa yang dipisahkan.

Pengeluaran pembiayaan mencakup:

- Pembentukan dan penambahan dana cadangan digunakan untuk membiayai kegiatan yang sudah ditetapkan dalam pembentukan dana cadangan. Dana cadangan tidak dapat sekaligus dibebankan dalam 1 tahun anggaran yang ditetapkan dalam peraturan desa. Pembentukan dana cadangan ditetapkan dengan peraturan desa, paling sedikit memuat: penetapan tujuan pembentukan dana cadangan, program dan kegiatan yang akan dibiayai dari dana cadangan, besaran dan rincian tahunan dana cadangan yang harus dianggarkan, sumber dana cadangan, dan tahun anggaran pelaksanaan dana cadangan. Pembentukan dana cadangan dapat bersumber dari penyisihan atas penerimaan desa, kecuali dari penerimaan yang penggunaannya telah ditentukan secara khusus berdasarkan peraturan perundangundangan. Pembentukan dana cadangan ditempatkan pada rekening tersendiri. Penganggaran dana cadangan tidak melebihi tahun akhir masa jabatan Kepala Desa. 
- Penyertaan modal desa. Pemerintah desa dapat melakukan investasi pada Bumdes (Badan Usaha Milik Desa) atau badan swasta lain. Penyertaan modal ini dilakukan oleh kepala desa dan disetujui BPD setelah ada ketetapan peraturan desa. Penyertaan modal desa masuk dalam pengeluaran pembiayaan dan digunakan untuk menganggarkan kekayaan pemerintah desa yang diinvestasikan baik jangka pendek METODE PENELITIAN maupun jangka panjang.

Penelitian ini menggunakan metode kualitatif deskriptif. Menurut Bodgan dan Taylor dalam Moleong (2001: 3) bahwa penelitian kualitatif adalah "prosedur penelitian yang menghasilkan data deskriptif berupa kata-kata tertulis atau lisan dari orang-orang dan perilaku yang dpat diamati." Sementara itu, menurut Irawan (2007:60) bahwa metode penelitian deskriptif adalah penelitian yang bertujuan mendeskripsikan atau menjelaskan suatu hal seperti apa adanya. Oleh sebab itu, penelitian ini menggunakan desain penelitian kualitatif dengan pola pendekatan deskriptif yang bercirikan kegiatan pengumpulan, menggambarkan dan menafsirkan data.

Sehubungan dengan sumber data, Arikunto (2008: 114) mengatakan: "Sumber data dalam penelitian ini adalah subjek dari mana data diperoleh. Sementara untuk memperoleh informasi penelitian, maka digunakan informan. Moleong (2011: 90), mengemukakan bahwa "informan adalah orang yang dimanfaatkan untuk memberikan informasi tentang situasi dan kondisi latar penelitian".

Sementara itu, informan dalam penelitian ini, yakni:

1. Amad Nurani selaku Kaur Keuangan Desa Rantaupanjang Kiri, Kecamatan

Kubu
2. Rodiyanah selaku Kasi Pemerintahan Desa Rantaupanjang Kiri, Kecamatan Kubu

\section{HASIL DAN PEMBAHASAN}

\section{Peran Perangkat Desa dalam Pengalokasian Dana Desa}

Dalam Pasal 93 Peraturan Pemerintah Nomor 43 Tahun 2014 tentang Desa pengelolaan keuangan desa meliputi perencanaan, pelaksanaan, penatausahaan, pelaporan, dan Pertanggungjawaban.

Sesuai dari hasil wawancara dengan Kaur Keuangan Desa Rantaupanjang Kiri, Pengelolaan keuangan desa yang dilakukan di Desa Rantaupanjang Kiri juga melalui proses tersebut, dengan melakukan perencanaan, pelaksanaan, dan juga laporan pertanggungjawaban. Dalam pelaksanaan pengelolaan alokasi dana Desa. Kepala Desa menjadi penanggung jawab utama atas pelaksanaan pengalokasian dana ini,yang dibantu oleh perangkat-perangkat desa, selain perangkat-perangkat desa, komponen penting lain dalam desa seperti Kepala Dusun, RT, RW, BPK, dan komponen penting lain dalam desa juga ikut serta dalam pengalokasian dana desa. Peran perangkat desa dalam pengalokasian dana juga dinilai baik, karena semua perangkat desa ikut serta dalam proses alokasi dana sesuai dengan bidangnya masing-masing.

Pada 2019, anggaran alokasi dana desa yang diterima pemerintah desa, digunakan untuk penyelenggaraan pemerintah desa, biaya pemberdayaan masyarakat, dan juga biaya kepentingan kantor desa. Biaya didapatkan secara bertahap sebanyak tiga tahap pencairan, yakni tahap pertama sebanyak $20 \%$, tahap kedua $40 \%$, dan ketiga 40\%.. Dalam rangka mendukung kelancaran pelaksanaan pengelolaan dana desa, maka melalui proses perencanaan, pelaksanaan, dan laporan pertanggungjawaban, kepala desa dan para komponen desa melakukan proses pengalokasian dana sebagai berikut. 


\section{Perencanaan}

Perencanaan awal dalam alokasi dana desa yang merupakan tahap paling awal dari kegiatan pengelolaan alokasi dana desa. Kegiatan perencanaan bertujuan untuk menyusun rencana kegiatan sekaligus menetapkan alokasi anggaran yang dituangkan dalam Daftar Rencana Kegiatan (DRK) dan Rencana Anggaran Belanja (RAB). Di sini para perangkat desa maupun komponen lain berpartisipasi dalam perencanaan dan mengasumsikan pendapatnya dalam perencanaan alokasi dana, baik anggaran pembiayaan kantor desa, anggaran pembinaan warga desa, pemberdayaan desa, pembangunan, belanja dalam pembangunan desa.

\section{Pelaksanaan}

Pelaksanaan merupakan realisasi dari perencanaan yang telah dibuat sebelumnya, alokasi dana desa (ADD) yang telah didapatkan direalisasikan kepada rencana yang telah dibuat pada tahap perencanaan, beberapa realisasi anggaran yang dialokasikan di Desa Rantaupanjang Kiri, yakni digunakan untuk hal-hal berikut. Pertama, penyelenggaraan pemerintahan desa. Pengalokasian dana pertama digunakan untuk penyelenggaraan pemerintah desa yang berhubungan dengan kebutuhan perkantoran desa, kebutuhankebutuhan para perangkat desa, seperti penghasilan yang diberikan kepada kepala desa dan perangkat desa lainnya, tunjangan, insentif kepada komponen desa, operasional kantor $(10 \%$ dari ADD $)$, operasional BPD (10\% dari 10\% ADD), dan kegiatan-kegiatan yang dilakukan di area kantor desa.

Kedua, bidang pembinaan. Bidang pembinaan merupakan kegiatan yang berhubungan dengan pembinaan masyarakat desa, yakni program-program yang dapat meningkatkan perkembangan, ketertiban, wawasan, kreativitas, dan sosialisasi dan juga keagamaan di masyarakat Desa Rantaupanjang Kiri. Alokasi dana desa ini digunakan untuk peningkatan keamanan dan ketertiban yang diberikan kepada siskamling, kegiatan sosialisasi hukum, kegiatan lomba MTQ tingkat desa yang berguna untuk memotivasi masyarakat dalam mempelajari agama, kegiatan karang taruna sebagai pembinaan dan pemberdayaan kepada para remaja, misalnya dalam bidang keorganisasian, ekonomi, olahraga, keterampilan, advokasi, keagamaan dan kesenian. Selain itu anggaran desa dalam bidang pembinaan ini juga dialokasikan untuk pemberian insentif kepada imam masjid, guru mengaji dengan tujuan peningkatan keilmuan agama kepada masyarakat.

Ketiga, bidang pemberdayaan kemasyarakatan. Pengalokasian dana di bidang ini digunakan untuk kegiatankegiatan yang bertujuan meningkatkan kinerja para komponen desa, pengalokasian dana desa ini digunakan untuk kegiatan pelatihan peningkatan kapasitas aparatur desa, kegiatan pelatihan peningkatan kapasitas perangkat desa, kegiatan pelatihan peningkatan kapasitas BPD.

Keempat, bidang pembangunan. Pelaksanaan pengalokasian dana di bidang pembangunan ini digunakan untuk kegiatan dan program-program yang mempermudah masyarakat Desa Rantaupanjang Kiri. Alokasi dan desa pada bidang ini digunakan untuk kegiatan pembuatan peta desa, penyelenggaraan posyandu, dll.

\section{Laporan Pertanggungjawaban}

Laporan pertanggungjawaban merupakan gabungan dari tanggung jawab dan hasil laporan selama kegiatan dalam pengalokasian dana desa yang dilakukan oleh para perangkat desa sebagai pengatur dana desa dan juga komponen desa lainnya yang ikut berpartisipasi dalam pengembangan desa. Pertanggungjawaban ini dilaporkan kepada Dinas PMD dan masyarakat desa. Dalam laporan ini akan dijabarkan mengenai 
alokasi dana yang digunakan dalam kegiatankegiatan desa dan juga kebutuhan perangkat desa.

- Dana desa yang dialokasikan untuk bidang penyelenggaraan pemerintahan desa dan bidang pembinaan, yakni sebesar Rp694.788.309,00 dan yang digunakan untuk bidang pemerintahan

Tabel 1 Pendapatan Dana Desa Rantaupanjang Kiri

\begin{tabular}{|c|l|c|c|}
\hline NO & \multicolumn{1}{|c|}{ DANA DESA } & SUMBER & JUMLAH \\
\hline 1 & Alokasi Dana Desa (ADD) TA. 2019 & Pemda & Rp694.788.309,00 \\
\hline 2 & Dana Desa/KEP.DD/K TA. 2019 & Pusat & Rp785.468.000,00 \\
\hline 3 & Dana Desa/KEP.DD/K (SILPA 2018) & Pusat & Rp299.451.200,00 \\
\hline 4 & Alokasi Dana Desa Terutang 2018 & Pemda & Rp126.330.761,00 \\
\hline 5 & Alokasi Dana Desa Terutang 2017 & Pemda & Rp173.171.654,00 \\
\hline & TOTAL & & Rp2.079.209.924,00 \\
\hline
\end{tabular}

Tabel 2 Alokasi Dana Bidang Penyelenggaraan Pemerintah Desa

\begin{tabular}{|c|c|c|}
\hline NO & URAIAN & JUMLAH \\
\hline 1 & $\begin{array}{l}\text { Penghasilan Tetap dan Tunjangan Penghulu dan } \\
\text { Perangkat Kepenghuluan }\end{array}$ & Rp227.400.000,00 \\
\hline 2 & Operasional Perkantoran (OP) 10\% dari ADK & Rp50.000.000,00 \\
\hline 3 & Tunjangan BPKep & Rp63.600.000,00 \\
\hline 4 & $\begin{array}{l}\text { Operasional BPKep (OP) 10\% DARI 10\% dari } \\
\text { Operasional Kantor }\end{array}$ & Rp5.000.000,00 \\
\hline 5 & Insentif RT/RW & Rp90.000.000,00 \\
\hline 6 & Keg. Pengisian dan Penginputan Profil Kep. & Rp6.000.000,00 \\
\hline 7 & Keg. Penggangkatan Rastra & Rp7.062.000,00 \\
\hline 8 & Keg. Pelaksanaan Musrenbang Kep. & Rp5.000.000,00 \\
\hline 9 & Keg. Penyusunan RKP Kepenghuluan & Rp5.000.000,00 \\
\hline 10 & Keg. Penyusunan APBKep & Rp5.000.000,00 \\
\hline 11 & Keg. Penyusunan LPJ Penghulu & Rp5.000.000,00 \\
\hline \multicolumn{2}{|r|}{ TOTAL } & Rp469.062.000,00 \\
\hline
\end{tabular}

Tabel 3 Alokasi Dana Bidang Pembinaan

\begin{tabular}{|c|c|c|}
\hline NO & URAIAN & JUMLAH \\
\hline
\end{tabular}




\begin{tabular}{|c|c|c|}
\hline 1 & Keg. Peningkatan Keamanan dan Ketertiban & Rp3.600.000,00 \\
\hline 2 & $\begin{array}{l}\text { Keg. Sosialisasi Produk Hukum Terbaru Terkait } \\
\text { Pengelolaan Keuangan di Desa }\end{array}$ & Rp6.000.000,00 \\
\hline 3 & Keg. Pembinaan Sanggar Seni & Rp2.000.000,00 \\
\hline 4 & Keg. MTQ Tingkat Kepenghuluan & Rp20.000.000,00 \\
\hline 5 & Keg. Peringatan Hari Besar Islam (PHBI) & $10.000 .000,00$ \\
\hline 6 & Keg. Hari Besar Nasional (17 AGUSTUS) & Rp5.000.000,00 \\
\hline 7 & Insentif Imam Masjid & Rp7.200.000,00 \\
\hline 8 & Insentif Gharim Masjid & Rp3.600.000,00 \\
\hline 9 & Insentif Guru Mengaji Tradisional & Rp34.200.000,00 \\
\hline 10 & $\begin{array}{l}\text { Keg. Pemberdayaan Lembaga Kepemudaan/Karang } \\
\text { Taruna }\end{array}$ & Rp5.000.000,00 \\
\hline 11 & Keg. Pembinaan Keolahragaan & Rp10.000.000,00 \\
\hline 12 & Keg. Pembinaan LPMKep & Rp8.000.000,00 \\
\hline 13 & Keg. Pembinaan Pkk KepenghuluaN & Rp10.000.000,00 \\
\hline 14 & Keg. Pembinaan Dasa Wisma & Rp2.000.000,00 \\
\hline \multicolumn{2}{|r|}{ TOTAL } & Rp126.600.000,00 \\
\hline
\end{tabular}

Tabel 4 Alokasi Dana Bidang Pemberdayaan Masyarakat Desa

\begin{tabular}{|c|l|c|}
\hline NO & \multicolumn{1}{|c|}{ URAIAN } & JUMLAH \\
\hline 1 & $\begin{array}{l}\text { Keg. Pelatihan Peningkatan Kapasitas Aparatur } \\
\text { Penghulu }\end{array}$ & Rp20.000.000,00 \\
\hline 2 & $\begin{array}{l}\text { Keg. Pelatihan Peningkatan Kapasitas Perangkat } \\
\text { Kepnghuluan }\end{array}$ & Rp30.000.000,00 \\
\hline 3 & $\begin{array}{l}\text { Keg. Pelatihan Peningkatan Kapasitas BPKEP } \\
\text { Kepnghuluan }\end{array}$ & $\mathbf{R p 8 0 0 0 0 0 0 0 0 0 0 0 0 0 0 0 0}$ \\
\hline
\end{tabular}

Tabel 5 Alokasi Dana Bidang Pembangunan Desa

\begin{tabular}{|c|l|c|}
\hline NO & \multicolumn{1}{|c|}{ URAIAN } & JUMLAH \\
\hline 1 & Insentif Guru PAUD (3 orang) & Rp10.800.000,00 \\
\hline 2 & Keg. Penyelenggraan Posyandu (2 unit) & Rp12.000.000,00 \\
\hline 3 & Keg. Pembuatan Peta Desa & Rp6.000.000,00 \\
\hline 4 & Keg. BBGRM Kepenghuluan & Rp5.000.000,00 \\
\hline
\end{tabular}




\begin{tabular}{|c|c|}
\hline TOTAL & Rp33.800.000,00 \\
\hline
\end{tabular}

- Dana Desa/KEP.DD/K TA. 2019 diberikan sebesar Rp785.468.000,00 dan digunakan untuk alokasi dana bidang pemberdayaan masyarakat sebesar Rp80.000.000,00 dan sisanya sebesar Rp705.468.000,00 digunakan untuk dana bidang pembangunan desa.

- Dana pembangunan desa dialokasikan sebesar Rp705.468.000,00 dan digunakan sebesar Rp33.800.000,00 dan sisanya sebesar Rp671.668.000,00 digunakan untuk pembangunan. Maka total dana sisa setiap bidang yang digunakan untuk pembangunan desa sebesar Rp770.794.309,00

Tabel di atas telah memperlihatkan jelas mengenai dana yang dialokasikan kepada perangkat desa, aparatur desa, masyarakat, maupun dalam pembangunan. Sesuai dengan komponen dalam anggaran desa yang dijelaskan Menurut Permendagri Nomor 113 Tahun 2014, komponen desa, yakni ada tiga, yaitu pertama pendapatan, pendapatan atau pemasukan yang didapatkan di Desa Rantaupanjang Kiri didapatkan dari transfer pusat dan pemda. Yang belanja desa, dana yang didapatkan tersebut digunakan untuk belanja desa, belanja desa di Desa Rantaupanjang Kiri terdiri dari alokasI dana bidang-bidang yang dijelaskan di tabel, digunakan untuk anggaran kantor desa, pemberdayaan masyarakat pembangunan, dan lain-lain. Yang ketiga adalah pembiayaan, pembiayaan merupakan sisa dari anggaran yang diberikan yang telah dibelanjakan dan pembiayaan ini dapat digunakan sebagai dana darurat ataupun pencairan cadang dan di Desa Rantaupanjang Kiri pembiayaan digunakan untuk dana pembangunan desa.

\section{Hambatan dalam Pengalokasian Dana Desa}

Menurut hasil wawancara yang dilakukan kepada Kaur Keuangan Desa Rantaupanjang Kiri, hambatan yang dirasakan dalam pengalokasian dana desa ini, yakni kadang kala terjadinya keterlambatan transfer tahap ke tiga dana dari pemda maupun pusat. Dana yang seharusnya di transfer pada tahap tiga terkadang kurang tepat waktu dari yang telah dijadwalkan, maka akan terjadi pula keterlambatan dalam kegiatan-kegiatan yang direncanakan.

Selain itu, hambatan yang dirasakan, yakni jauhnya jarak tempuh antar desa membuat sulit pula datangnya barang atau keperluan desa yang diambil dari kota, karena akses yang sulit, jalanan yang kurang bagus, maka transfer barangnya menjadi kendala dan menyebabkan keterlambatan. Terkadang pada musim hujan juga terjadi hambatan, jika terjadi hujan, karena keadaan akses jalan menuju desa kurang mendukung, maka akan terjadi becek dan sulit untuk kendaraan lewat. Itulah beberapa hambatan yang dirasakan oleh perangkat desa dalam pengalokasian dana desa.

\section{SIMPULAN}

Pengalokasian dana desa di desa Rantaupanjang Kiri melibatkan banyak pihak, baik perangkat desa, komponen desa lainnya, yakni aparatur desa. Dalam pengalokasian dana ini perangkat desa memiliki peran penting mengingat setiap anggaran yang didapatkan tersalurkan kepada desa dan diurus oleh perangkat desa. Kepala desa selaku penanggung jawab utama dalam pengalokasian dana tentu memiliki tanggung jawab besar, maka para perangkat desa membatu kepala desa dalam pengalokasian dana. Dari hasil wawancara kepada Kaur Keuangan Desa Rantaupanjang Kiri, para perangkat desa dinilai bekerja dengan baik dalam pengalokasian dana. Dana juga dialokasikan sebagai mana mestinya.

Hambatan yang dirasakan dalam mangalokasikan dana ini ialah dana yang terlambat cair dari pemda maupun pusat, 
kemudian juga kendala pada transfer kebutuhan desa yang sulit karena akses desa yang cukup jauh dari pusat, cuaca juga menjadi kendala mengingat ketika hujan maka akses jalanan menuju Desa Rantaupanjang Kiri akan sulit ditembus karena becek dan banjir.

\section{SARAN}

Saran kepada kepala desa dan para perangkat desa, dikarenakan kinerja perangkat yang sudah baik sesuai ketentuan maka diharapkan untuk dipertahankan.

Saran berikutnya pengalokasian dana desa lebih dialokasikan dalam pengembangan agar masyarakat desa, meskipun jarak desa jauh dari akses kota, namun dapat tetap mengikuti perkembangan zaman.

\section{DAFTAR PUSTAKA}

$\begin{array}{lll}\text { Erni } & \begin{array}{l}\text { Tisnawati } \\ \text { Saefullah, Pengantar Manajemen, Jakarta: }\end{array} \\ & \text { Kencana Perdana Media Goup, 2009 } \\ \text { Hanif } & \begin{array}{l}\text { Nurcholis, } \\ \text { dan Penyelenggaraan }\end{array} & \text { Pertumbuhan } \\ & \text { Desa. Jakarta: Erlangga } & \end{array}$

$\begin{array}{lll}\text { Moleong, } & \text { L.J. } & \text { (2011). Metodologi }\end{array}$ Penelitian Kualitatif Edisi Revisi. Bandung: $\quad$ PT. Remaja Rosdakarya.

Irawan, Prasetya. 2007. Analisis Kinerja: Panduan Praktis Untuk Menganalisis

Kinerja, Kinerja Proses dan Kinerja Pegawai. Jakarta. Lembaga Administrasi Negara.

Sumaryadi,I Nyoman.(2005). Perencanaan Pembangunan Daerah Otonom dan Pemberdayaan Masyarakat.Jakarta,Citra Utama

Widjaja, HAW. 2005. Otonomi Desa Merupakan Otonomi yang Asli Bulat dan Utuh. Jakarta: PT Raja Grafindo Persada

\section{Peraturan Perundang-Undangan}

Undang-Undang Nomor 6 Tahun 2014 tentang Desa
Undang Nomor 22 Tahun 1999 yang telah direvisi melalui Undang-Undang Nomor 32 Tahun 2004 tentang Pemerintahan Desa.

Permendagri Nomor 84 Tahun 2015 tentang Susunan Organisasi dan Tata Kerja Pemerintah Desa (SOTK)

Peraturan Menteri Dalam Negeri Nomor 37 tahun 2007 tentang Pedoman Pengelolaan Keuangan Desa.

Peraturan Pemerintah Nomor 43 Tahun 2014 tentang Desa Pasal 93 pengelolaan keuangan desa

\section{Sumber Lain}

https://www.kemenkeu.go.id/media/6750/ bukusaku-dana-desa.pdf

KBBI. (2016). Kamus Besar Bahasa Indonesia. Diunduh pada 28 Juli 2019 dari https:// kbbi.kemdikbud.go.id/entri/modifikasi 
Virioner - 2

Vol. 12 | No. |April 2020: 297-308 